\title{
Organization of a dispersed repeated DNA element in the Zamia genome
}

\author{
D. CAFASSO ${ }^{1 *}$, S. COZZOLINO ${ }^{1}$, N.J. VEREECKEN ${ }^{2}$, P. DE LUCA ${ }^{3}$ and G. CHINALI ${ }^{4}$ \\ Dipartimento di Biologia Strutturale e Funzionale, Complesso Universitario Monte S. Angelo, \\ Università degli Studi di Napoli Federico II, Via Cinthia, I-80126 Napoli, Italy ${ }^{I}$ \\ Behavioural and Evolutionary Ecology, Free University of Brussels, \\ Av. F.D. Roosevelt 50, B-1050 Brussels, Belgium ${ }^{2}$ \\ Dipartimento delle Scienze Biologiche, Università degli Studi di Napoli Federico II, \\ Via Foria 223, I-80139 Napoli, Italy ${ }^{3}$ \\ Dipartimento di Medicina Clinica e Sperimentale, Facoltà di Medicina e Chirurgia, \\ Università di Napoli Federico II. Via Pansini 5, I-80131 Napoli, Italy ${ }^{4}$
}

\begin{abstract}
Occurrence and genomic organization of dispersed elements containing $\mathrm{ZpS1}$ satellite repeats have been investigated in a wide representation of species of the old plant genus Zamia (Zamiaceae, Cycadales). In Z. paucijuga, the ZpS1 repeat is organized as long satellite DNA arrays and as short arrays inserted into AT-rich dispersed elements. A comparative study by Southern analysis shows that these unusual dispersed elements containing the ZpS1 repeat are present with different organizations in all investigated Zamia species. In some species these elements are present with a low copy number, while in other species secondary amplification events, involving specific sequence clusters, appear to have generated characteristic dispersed elements in a high copy number. Among Zamia species, several groups share similar restriction patterns, as the Zamia loddigesii complex and the Caribbean species suggesting a general correlation between organization and genomic representation of the dispersed repeated sequence and the pattern of phyletic relationships in the genus. However, the finding of different patterns also among closely related species suggests a complex history of amplifications and losses of these dispersed repetitive elements that cannot be always easily traced through the phylogenetic reconstruction of this ancient plant group.
\end{abstract}

Additional key words: cycads, dispersed sequences, genome evolution, repetitive DNA.

\section{Introduction}

Repetitive DNA sequences represent a large proportion of higher plant genomes and are implicated as a major contributor to variation in DNA content among organisms of similar complexity (Harding et al. 1992, Charlesworth et al. 1994, Kubis et al. 1998, Sharma and Raina 2005). DNA content varies largely among plant species and, comparing to angiosperm, gymnosperms typically have larger genomes: their modal C-value (15.8 pg) is over 20 times greater than in angiosperms (Leitch and Bennett 2002). Large C-values ( $\geq 14.0 \mathrm{pg}$ ) is even typical in cycads (mean $1 \mathrm{C}=14.7 \mathrm{pg}$ ), regarded as the basal group of gymnosperms (Ohri and Khoshoo 1986). Investigations of genome organization in these old plant groups are thus important to our understanding of

the evolution of plant genome. At the same time, the study of the physical organization of repetitive DNA sequences and of the degree of conservation and/or divergence of these sequences among related species may represent a way to gain knowledge of the evolution of and within a species group (Bedbrook et al. 1980, Bachmann and Sperlich 1993, Capriglione et al. 1998). In fact, repetitive DNA not only represents a dynamic and fast evolving component of the eukaryotic genome, but may also show conservation within taxonomic groups, thus providing evidence for phylo-genetic relationships (King et al. 1995, Pich et al. 1996, Alix et al. 1998, Kubis et al. 1998, Macas et al. 2006).

Cycads are an archaic and isolated group of seed

Received 15 February 2007, accepted 23 November 2007.

Abbreviations: DAPI - 4,6-diamidino-2-phenylindole; DIG - digoxigenin; PCR - polymerase chain reaction.

Aknowledgments: The authors thank G. Odierna and O. Picariello for discussions about repetitive DNA organization, S. Fioretti and B. Menale, members of the staff of Naples Botanical Garden, for their continuous work in maintaining the living collection of cycads. They also thank M. Longrigg for language revision. Funding for this study was provided by the PRIN program.

* Corresponding author; fax: (+39) 081450165, e-mail: cafasso@unina.it 
plants consisting of three families (Johnson 1959, Norstog and Nicholls 1997, Stevenson 1990), 11 genera and over 150 species (Stevenson 1992). The genus Zamia (Zamiaceae) has the widest ecological and morphological diversity among all cycad genera, ranging from arborescent species to species with small, subterranean stems, to epiphytic taxa (Stevenson et al. 1995, Norstog and Nicholls 1997). Fossil and phylogenetic evidences indicate a derivate position for this genus among the neotropical cycads (Norstog and Nicholls 1997). Zamia is also unique among cycads in showing interspecific and intraspecific karyotype variation (Marchant 1968, Norstog 1980, Moretti 1990a,b). Occurrence of Robertsonian changes, such as centric fission of metacentric chromosome or centric fusion of telocentric chromosomes, has been suggested to explain the causes of the high chromosome variability reported in Zamia (Norstog 1980, Moretti and Sabato 1984, Schutzman et al. 1988, Moretti 1990b, Moretti et al. 1991).

Repetitive elements may show different organization in the genome, typically ranging from a more or less even dispersion over genome (dispersed elements) to localization in few large arrays (satellite DNA) (Kubis et al. 1998).

A family of repeated sequences with an intermediate and unusual distribution pattern has been recently characterized in the genome of Zamia paucijuga (Cafasso et al. 2003). In this species, a 320 bp-long repeat sequence named $\mathrm{ZpS} 1$ (GeneBank Accession number:
AJ315634), is organized both as typical satellite DNA arrays located in subtelomeric position of most chromosomes and in small dispersed repeated elements of 1 - 6 repeats which are flanked by AT-rich lateral arms (GeneBank Accession numbers: AJ315635, AJ416334). While the ZpS1 satellite DNA arrays are recognizable after digestion with the restriction endonucleases ApaI and $E c o \mathrm{RV}$, the dispersed repeated elements are recognizable after digestion with the restriction endonuclease EcoRI which digests the AT-rich flanking elements, but not the ZpS1 satellite arrays (Fig. 1). These unusual dispersed repeated elements have been likely originated by a rearrangement of pre-existing satellite DNA repeats that have become inserted into an AT-rich sequence by site-specific recombination during the long life history of this ancient plant group (Cafasso et al. 2003).

Preliminary analysis indicated that these dispersed repeated elements are present in other Zamia species (Cafasso et al. 2003). To investigate the occurrence, representation and genomic organization of these dispersed elements within the genus Zamia, Southern blot and PCR experiments has been carried out on genomic DNAs of several Zamia species representative of all major clades recognized in the genus (Caputo et al. 2004).

Specifically, we asked how widespread (and consequently how old) these dispersed repeated elements are among members of genus Zamia and which rearrangements occurred in their organization in the different phyletic lineages of this ancient plant group.

\section{Materials and methods}

Synthesis of digoxigenin-labelled DNA probes: Digoxigenin (DIG)-labeled probes for hybridization experiments were obtained by PCR amplification by adding 11-dUTP in the polymerase chain reaction (PCR DIG probe synthesis kit, Boehringer, Mannheim, Germany). Probes of $\mathrm{ZpS} 1$ repeat were amplified from clones obtained from genomic DNA (Cafasso et al. 2003) using the universal M13 forward and reverse primers. Two other probes were obtained from genomic DNA with the primer pairs Z1-Z5 and Z4-Z8 (Cafasso et al. 2003). The first primer pair selectively amplifies the AT-rich element flanking the $\mathrm{ZpS1}$ dispersed repeats, while the probe obtained with the second primer pair is homologous to both $\mathrm{ZpS1}$ repeat and AT-rich element (Fig. 1; Cafasso et al. 2003). Unincorporated nucleotides were removed from probes by Microcon 100 column filtration (Amicon, Millipore, Bedford, USA).

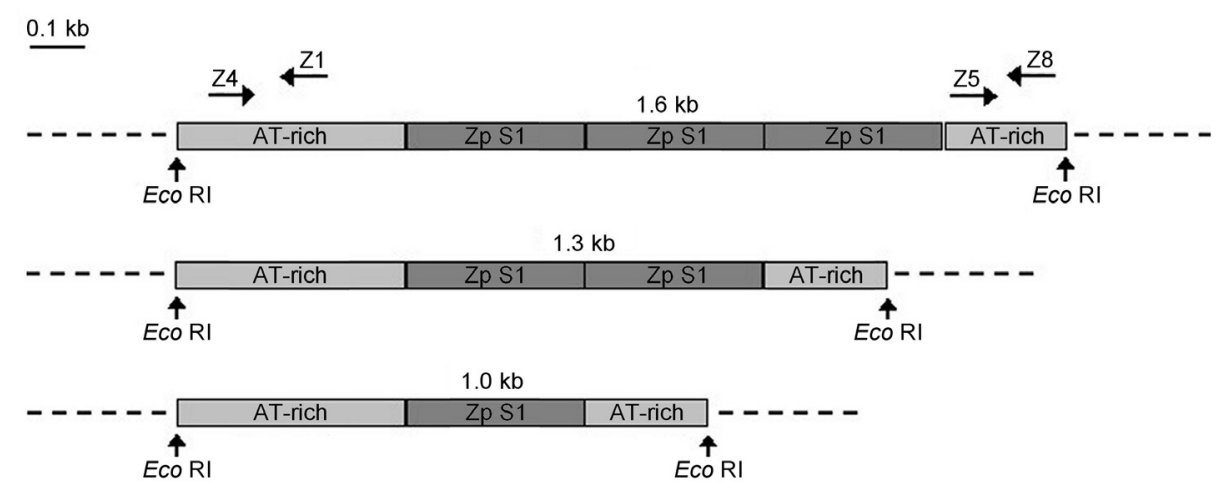

Fig. 1. Diagram illustrating the structure of the dispersed repeated elements containing one (1.0 kb long), two (1.3 kb long) or three (1.6 kb long) ZpS1 repeats, respectively. Restriction sites for EcoRI enzyme and position and orientation of the Z1-Z5 and Z4-Z8 primer pairs are indicated by arrows. Dark blocks correspond to the $\mathrm{ZpS1}$ satellite repeat and bright blocks correspond to the AT-rich flanking elements. 
Southern blot analysis: Genomic DNA from Zamia species was isolated from fresh or silica gel-dried leaf material as described by Doyle and Doyle (1987). After treatment with RNAse, the DNA amount was estimated spectrophotometrically. All plant material came from the botanical collections of the Naples Botanical Garden and the New York Botanical Garden, or has been field collected by the authors (Table 1).

The same exact amount of genomic DNA (500 ng) of different Zamia species (Table 1) was digested overnight at $37{ }^{\circ} \mathrm{C}$ with an excess of EcoRI or ApaI restriction endonucleases $\left[3-5 \mathrm{U}^{-1}\right.$ (DNA)] to avoid partial digestion, electrophoresed in a $1.3 \%$ agarose gel, and transferred and fixed to a nylon membrane according to standard procedures (Sambrook et al. 1989). Filters were hybridized at $65{ }^{\circ} \mathrm{C}$ with the DIG-labeled probe amplified with primer pair Z4-Z8 (Fig. 1), and washed at same temperature in $0.1 \%$ SDS, $0.1 \times$ SSC (stringent conditions). The DIG detection kit was used to detect hybrid bands, following the manufacturer's instructions.

Flow cytometry analyses: Estimation of relative genome content was performed for all species for which fresh leaf material was available (i.e. all Zamia species, but Z. manicata, present in the collection of Naples Botanical Garden, see Table 1). Flow cytometry is based on the measure of fluorescence emission by light-excited, stained interphase nuclei (Uberall et al. 2004, Dolezel

Table 1. List of examined Zamia species with authors, geographic origins of samples, places of cultivation (NBG - Naples Botanical Garden; NYBG - New York Botanical Garden; FC - field collected) and accession numbers.

\begin{tabular}{|c|c|c|c|}
\hline Zamia species & Geographic origins & Cultivation & Accession No. \\
\hline Z. neurophyllidia Stevenson & Panama & NYBG & $\mathrm{Z} 1$ \\
\hline Z.acuminata Oerested ex Dyer & Panama & NYBG & $\mathrm{Z} 2$ \\
\hline Z. tuerckeimii Smith & Guatemala & NYBG & $\mathrm{Z3}$ \\
\hline Z. ipetiensis Stevenson & Panama & NYBG & $\mathrm{Z} 4$ \\
\hline Z. cremnophila Vovides, Schutzman, Dehgan & Tabasco (Mex) & $\mathrm{FC}$ & $\mathrm{Z} 5$ \\
\hline Z. portoricensis Urban & Puerto Rico & NBG & Z6 \\
\hline Z. pumila Linnaeus & Dominican Republic & NBG & $\mathrm{Z7}$ \\
\hline Z. purpurea Vovides, Rees, Vazquez Torres & Oaxaca (Mex) & $\mathrm{FC}$ & $\mathrm{Z} 8$ \\
\hline Z. muricata Willdenow & Colombia & NYBG & Z9 \\
\hline Z. wallisii Braun & Colombia & NBG & $\mathrm{Z} 10$ \\
\hline Z. skinneri Warszewicz ex Dietrich & Panama & FC & Z11 \\
\hline Z. inermis Vovides, Rees, Vazquez Torres & Veracruz (Mex) & NBG & $\mathrm{Z} 12$ \\
\hline Z. fisheri Miquel & San Luis Potosì (Mex) & NBG & $\mathrm{Z} 13$ \\
\hline Z. vazquezii Stevenson, Sabato, Moretti & San Luis Potosì (Mex) & NBG & Z14 \\
\hline Z. soconuscensis Schutzman, Vovides, Dehgan & Chiapas (Mex) & NBG & $\mathrm{Z} 15$ \\
\hline Z. poeppigiana Martius, Eichler & Ecuador & $\mathrm{FC}$ & Z16 \\
\hline Z. amplifolia Hort ex Masters & Colombia & NBG & $\mathrm{Z} 17$ \\
\hline Z. standley Schutzman & Honduras & $\mathrm{FC}$ & Z18 \\
\hline Z. roezlii Regel & Colombia & FC & Z19 \\
\hline Z. lecointei Ducke & Brasile & NYBG & $\mathrm{Z} 20$ \\
\hline Z. manicata Linden ex Regel & Colombia & NBG & $\mathrm{Z} 21$ \\
\hline Z. chigua Seemann & Colombia & $\mathrm{FC}$ & $\mathrm{Z} 22$ \\
\hline Z. sylvatica Chamberlain & Oaxaca (Mex) & NBG & $\mathrm{Z} 23$ \\
\hline Z. splendens Schutzman & Chiapas (Mex) & NBG & Z24 \\
\hline Z. integrifolia Linnaeus fil. in Aiton & Cuba & NBG & $\mathrm{Z} 25$ \\
\hline Z. picta Dyer & Guatemala & $\mathrm{FC}$ & Z26 \\
\hline Z. spartea De Candolle & Oaxaca (Mex) & NBG & $\mathrm{Z} 27$ \\
\hline Z. boliviana (Brogniart) A. De Candolle & Bolivia & $\mathrm{FC}$ & $\mathrm{Z} 28$ \\
\hline Z. loddigesii Miquel & Veracruz (Mex) & $\mathrm{FC}$ & Z29 \\
\hline Z. furfuracea Linnaeus fil. & Veracruz (Mex) & NBG & $\mathrm{Z} 30$ \\
\hline Z. paucijuga Wieland & Oaxaca (Mex) & $\mathrm{FC}$ & $\mathrm{Z} 31$ \\
\hline Z. paucijuga Wieland & Oaxaca (Mex) & FC & $\mathrm{Z} 32$ \\
\hline Z. paucijuga Wieland & Michoacan (Mex) & NBG & $\mathrm{Z} 33$ \\
\hline Z. paucijuga Wieland & Nayarit (Mex) & NBG & $\mathrm{Z} 34$ \\
\hline Z. paucijuga Wieland & Nayarit (Mex) & NBG & $\mathrm{Z} 35$ \\
\hline Z. paucijuga Wieland & Jalisco (Mex) & NBG & Z36 \\
\hline Z. polymorpha Stevenson, Moretti, Vàzquez Torres & Campeche (Mex) & $\mathrm{FC}$ & $\mathrm{Z} 37$ \\
\hline Z. polymorpha Stevenson, Moretti, Vàzquez Torres & Campeche (Mex) & $\mathrm{FC}$ & $\mathrm{Z} 38$ \\
\hline Z. polymorpha Stevenson, Moretti, Vàzquez Torres & Quintana Roo (Mex) & NBG & Z39 \\
\hline Z. polymorpha Stevenson, Moretti, Vàzquez Torres & Belice & $\mathrm{FC}$ & $\mathrm{Z} 40$ \\
\hline Z. polymorpha Stevenson, Moretti, Vàzquez Torres & Belice & NBG & Z41 \\
\hline Z. polymorpha Stevenson, Moretti, Vàzquez Torres & Belice & NBG & $\mathrm{Z} 42$ \\
\hline
\end{tabular}


and Bartos 2005, Kovářová et al. 2007, Yang et al. 2008). The latter were released by chopping up fresh leaf fragments in Petri dishes using a razor blade, and they were stained with 4,6-diamidino-2-phenylindole (DAPI), which has the property of binding specifically to the chromosomes. The DNA-DAPI complexes of each species were then successively excited by the laser beam, which in turn produced specific wavelengths emission patterns depending on the DNA contents of the interphase nuclei. This emitted light was picked up by detectors, and produced DNA histograms that allowed comparing the patterns obtained among samples and inferring their relative genome content. As controls for the calibration of the flow cytometer (see also the procedure detailed by Aron et al. 2003) we used an accession of Zamia angustifolia. The genome content $(1 \mathrm{C}=12.05)$ of this species was previously determined by Ohri and Khoshoo (1986).

Quantitative dot blot analysis: The amount of the repeated DNA sequences in the Zamia species, for which sufficient DNA was available, was estimated by quantitative dot blot analysis using varying amounts of genomic DNA. A linearized plasmid DNA containing an insert of dispersed repeated sequence was used as a standard. After tissue extraction, the genomic DNA of the species used for the dot blot analysis was treated with RNAse, precipitated twice with one volume of $88 \%(\mathrm{v} / \mathrm{v})$ isopropyl alcohol $+0.2 \mathrm{M}$ potassium acetate and

\section{Results}

Southern blot analyses of DNA digested with the restriction endonuclease ApaI, which cuts the $\mathrm{ZpS} 1$ satellite repeat, showed that this repeated sequence displays the typical ladder pattern of satellite DNA in all species of Zamia examined, but was absent in the closely related genera Ceratozamia and Microcycas (data not shown).

Upon digestion with EcoRI (this enzyme does not cut the $\mathrm{ZpS1}$ satellite repeat, but only the AT-rich element flanking dispersed $\mathrm{ZpS1}$ repeats), the hybridization patterns of different Zamia species, revealed a variable occurrence and organization of the dispersed repeated elements.

Samples of all Zamia species examined by using flow cytometry yielded a virtually identical profile to the reference standard ( $Z$. angustifolia). This result suggests that it is fairly likely that all samples/species tested have very similar genome content (i.e., around $1 \mathrm{C}=12.05$ ). Quantitative dot blot analysis (Fig. 2), even if carried out only for a limited representation of taxa, from which a larger DNA amount was available, indicates that the amount of the tandem $\mathrm{ZpS} 1$ repeats varies from $3.0 \%$, as in row $\mathrm{A}$, to $0.3 \%$, as in row $\mathrm{F}$, of total DNA among species.

Southern blot experiments using a probe that recognizes both the $\mathrm{ZpS1}$ repeats and the AT-rich flanking sequences (i.e. the probe from $\mathrm{Z} 4-\mathrm{Z} 8$ primer pair resuspended in TE buffer. The DNA amount was estimated spectrophotometrically and then diluted at concentrations multiple of one another. Carrier sonicated salmon sperm DNA was added to each sample up to a final amount of $0.5 \mu \mathrm{g}$ DNA per sample to avoid errors due to differences in the hybridization kinetics. Dot blot was hybridized with a probe of the ZpS1 satellite DNA. The digoxigenin-labelling and hybridization detection procedures were the same as those used for Southern blot analysis.

PCR reaction: Dispersed sequences were amplified by PCR using $10 \mathrm{ng}$ of genomic DNA as template and 2.5 pmol of the primers in a final volume of $0.05 \mathrm{~cm}^{3}$. The primer pair Z4 and Z8 (Cafasso et al. 2003) was chosen to amplify a portion of the flanking AT-rich dispersed elements and the internal $\mathrm{ZpS} 1$ satellite arrays (Fig. 1). All PCR reactions were carried out in a thermal cycle (Applied Biosystem 9700, Foster City, USA) for 30 cycles with the following conditions: $30 \mathrm{~s}$ denaturation at $94{ }^{\circ} \mathrm{C}, 1 \mathrm{~min}$ annealing at $55^{\circ} \mathrm{C}, 2 \mathrm{~min}$ extension at $72{ }^{\circ} \mathrm{C}$; extension in the last cycle was for $7 \mathrm{~min}$. Amplification products were separated by electrophoresis on $1.5 \%$ agarose gel with TBE buffer and visualized by ethidium bromide staining. A $100 \mathrm{bp}$ ladder was used as a DNA molecular size standard (Pharmacia, Buckinghamshire, UK). Specificity of amplification products was then controlled by Southern blot hybridization with a probe of $\mathrm{ZpS} 1$ repeat as described above.

amplification) show that Zamia species belonging to different groups can be clearly distinguished according to

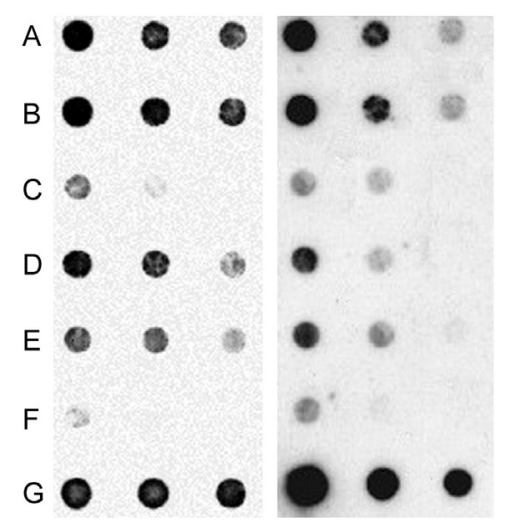

Fig. 2. Quantitative dot blot hybridization. Row A: Z. paucijuga (Z31); B: Z. furfuracea (Z30); C: Z. wallisii (Z10); D: Z. inermis (Z12); E: Z. fisheri (Z13); F: Z. amplifolia (Z17); $\mathrm{G}$ : (from left to right) 100, 50, $25 \mathrm{ng}$ of linearized DNA clone containing the dispersed repeated sequence. For each Zamia species the genomic DNA is in the same amounts as those in row G. Hybridization was carried out with a digoxygeninlabelled probe of the repeated sequence $\mathrm{ZpS1}$ (panel on the left) and of the AT-rich dispersed sequence amplified with Z1-Z5 primer pair (panel on the right). 


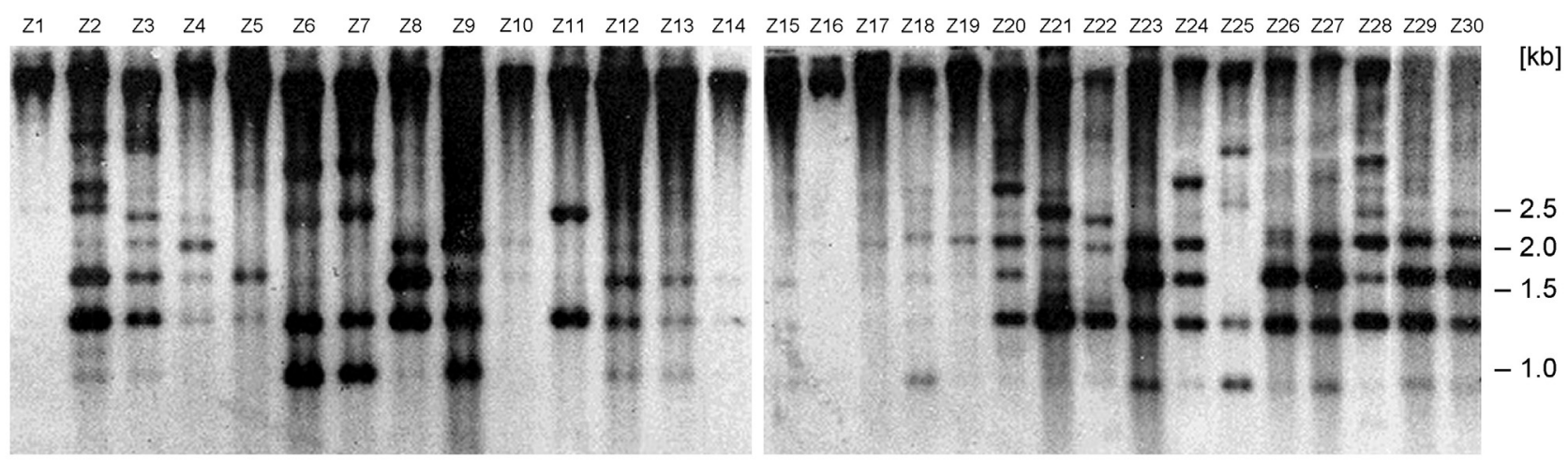

Fig. 3. Southern blots of genomic DNA of Zamia species. DNAs have been digested with EcoRI and hybridized with the dispersed repeated sequence amplified with Z4-Z8 primer pair. See Table 1 for the list of species.

their EcoRI digestion patterns (Figs. 3, 4). The observed differences in the overall signal intensity among the DNAs of the different species confirms that the copy number of $\mathrm{ZpS1}$ repeats organized as satellite DNA and as EcoRI dispersed repeated elements varies broadly among taxa. In these blots, hybridization bands of high molecular mass associated to DNA poorly digested by EcoRI, correspond to satellite DNA, while the discrete bands in the range $1-3 \mathrm{~kb}$ correspond to the dispersed element containing one (approx. $1 \mathrm{~kb}$ band) or more $\mathrm{ZpS1}$ repeats.

In some species containing $\mathrm{ZpS1}$ organized as satellite DNA, the dispersed repeated elements are hardly detectable, as in Z. vazquezii (Z14), Z. neurophyllidia (Z1) and Z. poeppigiana (Z16) or present in a very low copy number as in Z. amplifolia (Z17), Z. cremnophila (Z5), Z. roezli (Z19), Z. soconuscensis (Z15), Z. standley (Z18), Z. wallisii (Z10) which are characterized by a strong hybridization signal at high molecular mass (satellite DNA) and by none or only few faint clusters of dispersed elements (bands about 980, 1300, 1620, and 1940 bp long). To exclude that, in these species, the strong hybridization signal at high molecular mass was not the result of varying effectiveness of DNA digestion with the EcoRI restriction enzyme, we performed additional digestions as described in Cafasso et al. 2003. Briefly, we extensively digested the DNAs with EcoRI and then we recovered from gel the fraction of high molecular mass DNA that was not digested by EcoRI and redigested it with EcoRV that, as expected, generated the typical satellite DNA ladder of multimers of the $320 \mathrm{bp}$ repetitive unit (data not shown). However, PCR amplifications (Fig. 5) showed that dispersed elements containing $\mathrm{ZpS} 1$ repeats are present also in these species, suggesting that mutations leading to a complete or partial loss of the EcoRI site in the AT-rich element have occurred.

Secondary amplification events, involving only some clusters of dispersed repeated sequences, likely generated the different EcoRI digestion patterns and the high number of copies of dispersed repeated elements observed in all the other species. Among these, a group characterized by the abundant presence of clusters with very similar pattern is represented by the Mexican species of the Z. loddigesii group (Vovides and Olivares 1996, Stevenson et al. 1998). These are Z. furfuracea (Z30), Z. loddigesii (Z29), Z. picta (Z26), Z. paucijuga (Z31, Z32, Z33, Z34, Z35, Z36), Z. polymorpha (Z37, Z38, Z39, Z40, Z41, Z42), Z. purpurea (Z8), Z. spartea (Z27), Z. splendens (Z24), and Z. sylvatica (Z23). This group of species is clearly recognizable by the presence of four discrete clusters of repeats $(980,1300,1620,1940 \mathrm{bp})$, with the $1300 \mathrm{bp}$ and the $1620 \mathrm{bp}$ clusters, that contain two and three $\mathrm{ZpS} 1$ repeat copies respectively, being the most represented (Figs. 3 and 4).

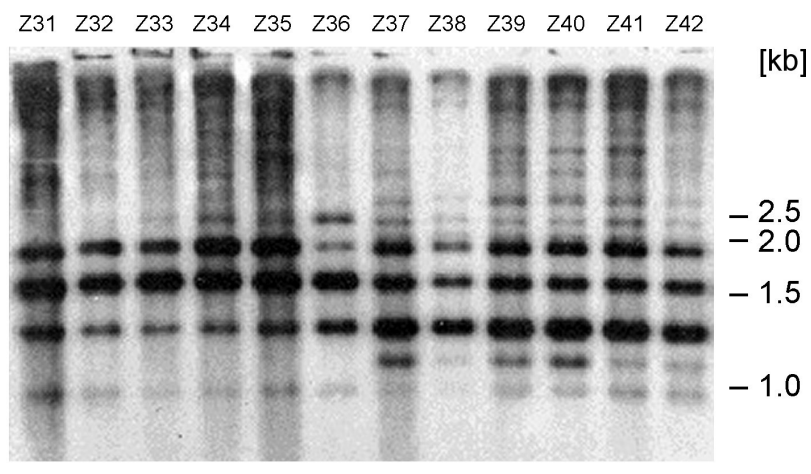

Fig. 4. Southern blots of genomic DNA of Z. paucijuga and $Z$. polymorpha. Accessions of Z. paucijuga and Z. polymorpha from different geographic origins have been digested with EcoRI and hybridized with the dispersed repeated sequence amplified with Z4-Z8 primer pair. See Table 1 for the list of species.

Together with the above described pattern, Z. picta (Z26) displays also an additional band at $2200 \mathrm{bp}$, $Z$. splendens (Z24) a faint band at $2900 \mathrm{bp}$, and Z. polymorpha (Z37, Z38, Z39, Z40, Z41, Z42) a faint band at $1200 \mathrm{bp}$.

When possible (e.g., with Z. paucijuga and $Z$. polymorpha, for which several individuals from different populations were available), the hybridization patterns were examined from different and unrelated 
geographic accessions. This resulted in a highly uniform pattern among accessions (Fig. 4). The Z. loddigesii (Z29) hybridization pattern, even if quantitatively less represented, is present also in the other Mexican isolated species Z. fisheri (Z18), Z. soconuscensis (Z15) and Z. inermis (Z12).

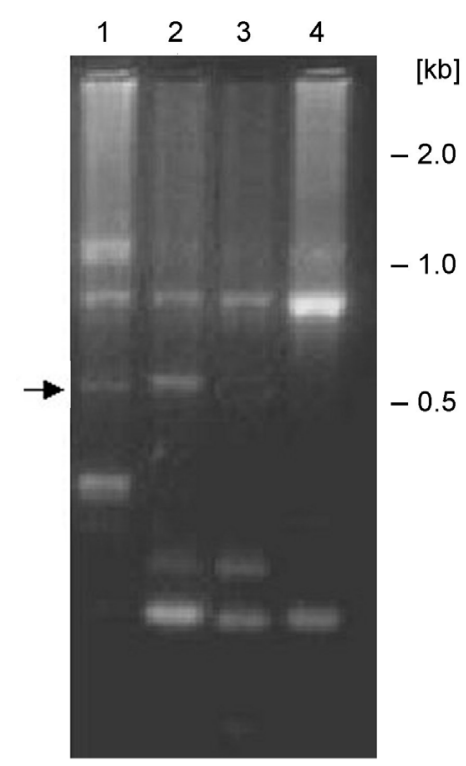

Fig. 5. PCR amplification with Z4-Z8 primer pair of the dispersed sequence containing the repeated sequences of a sub set of Zamia species whose southern blots showed none or few hybridization bands with the dispersed repeated sequence (see the text for explanation). Line 1: Zamia vazquezii, line 2: Z. poeppigiana, line 3: Z. neurophyllidia, line 4: Z. roezli. An arrow points the dispersed elements without the inserted satellite array.

\section{Discussion}

Both repetitive elements, the satellite repeats and the dispersed elements show a different representation within the genome of Zamia species examined by Southern blots analyses. Due to the fact that all species display very similar genome content at flow cytometry, the different estimated amounts of satellite repeat and of the dispersed elements among species, are likely due to their diverse representation in copy number in their genomes as consequence of different events of sequence amplifications. Cycads are very rare and slow-growing plants, but for Z. paucijuga, for which several accessions where present in the collection of Naples Botanical Garden, in situ hybridization of satellite repeat have showed that chromosomes hybridization sites were detected in the subtelomeric regions at one ends of most of the chromosomes confirming the satellite nature of this repeated sequence (Cafasso et al. 2003). Sorely, the need of several active growing root tip meristems used to generate chromosome preparations (Moretti 1990), does not allow to perform a similar analysis on other rare species less represented in living collections as botanical
Another clearly distinguishable group is represented by the Caribbean species $Z$. integrifolia (Z25), $Z$. portoricensis (Z6) and Z. pumila (Z7). These taxa are characterized by four strongly representative clusters (980, 1300, 2500, and $3700 \mathrm{bp}$ ), which provide an exclusive pattern for this group.

The Panamanian species Z. skinneri (Z11), is characterized by two large clusters of 1300 and $2500 \mathrm{bp}$. Similarly, Z. tuerckheimii (Z3) and the closely related $Z$. acuminata (Z2), both from the Guatemala-Panama region, are characterized by a similar basic pattern with 1300 and 1620 bp clusters being the most represented and with additional, fainter, higher mass EcoRI clusters (2500, 3200, and $4600 \mathrm{bp}$ ). Z. ipetiensis (Z4) from Panama is characterized by a pattern with the $1940 \mathrm{bp}$ long repeat as the most represented cluster but with no additional higher mass EcoRI clusters. Z. manicata (Z21) and Z. chigua (Z22), from the border region between Panama and Colombia, display a similar hybridization pattern (1300, 1450, 1620, 1940, 2400, and $2900 \mathrm{bp})$ with the $1300 \mathrm{bp}$ long cluster being the most represented. On the contrary, the Colombian Z. muricata (Z9) has a unique pattern with five strong bands $(980,1300,1620$, 1940, and $2260 \mathrm{bp}$ ) and additional higher mass EcoRI clusters.

Finally, two geographically related and morphologically similar species, $Z$. lecointei (Z20) and $Z$. boliviana (Z28), which range from Ecuador to the western Amazon Basin, display a similar pattern with the 1300 and $1940 \mathrm{bp}$ clusters being the most represented plus additional, higher mass EcoRI clusters (2260 and 2580 bp long) (Fig. 3).

gardens. Thus, with this limitation, we cannot asseverate if, species showing a different content of large tandem arrays also display different chromosome localization for these repeated elements.

The presence of $\mathrm{ZpS} 1$ hybridization signal in the ApaI digestions in all investigated species of Zamia, and its absence in the closely related genera, Ceratozamia and Microcycas, suggests that this repeated sequence was already present, as satellite DNA, in the last common ancestor of the genus Zamia. The finding of a common satellite repeat family in all investigated species of Zamia, whose stem lineage dates back at least to the early Cenozoic (Caputo et al. 2004) is an indication of an old generation event for the origin and amplification of this repetitive sequence.

At the same time, the ubiquity in the genus of dispersed elements containing satellite repeats strongly suggests that also this peculiar genomic rearrangement (i.e. the insertion of $\mathrm{ZpS1}$ satellite repeats in the AT-rich dispersed sequence) occurred relatively early in the evolutionary history of Zamia. 
This hypothesis is supported by the presence of these genomic rearrangements in all investigated species as showed by combined results of hybridization patterns and PCR amplifications. PCR amplifications (Fig. 5) showed, in fact, that dispersed AT-rich elements containing the repeated elements are present also in those species where hybridization patterns show only a strong hybridization signal at high molecular weight and none/little (Z. vazquezii, Z. neurophyllidia, Z. poeppigiana) or few hybridization bands ( $Z$. amplifolia, $Z$. roezli, $Z$. soconuscensis, Z. standley, Z. wallisii) of the dispersed repeated elements. This is likely due to a complete or partial loss of the EcoRI restriction site in the AT-rich element. The stochastic nature of such type of event can also explain why, species belonging to different phyletic Zamia lineages can show a similar hybridization pattern. For instance, Z. neurophyllidia (Z1), that does not display hybridization bands for the dispersed repeated elements, is a derivate rather than a basal taxon of the Central American species (Caputo et al. 2004). Similarly, $Z$. roezli $(\mathrm{Z} 10)$, that displays only few dispersed repeated elements, is a derivate species in the South American clade. Clearly, in these taxa, the absence of hybridization pattern (more likely due to a loose of EcoRI restriction sites) is a secondary derivate condition rather than a primitive condition.

The presence in all EcoRI Southern blots of strong $\mathrm{ZpS1}$ repeat hybridization signals in undigested DNA indicates that only a fraction of the repeated arrays is present in the dispersed clusters in all Zamia species. Accordingly, all investigated Zamia species, when digested with endonucleases (e.g. ApaI) that cut within the $\mathrm{ZpS} 1$ repeat, produced the ladder pattern typical of satellite DNA with the absence of undigested DNA (Cafasso et al. 2003).

The hybridization profiles show that different groups of species may be distinguished according to their EcoRI digestion patterns as consequence of different genome rearrangements of the dispersed repeated elements (Fig. 3) and indicate that this family of sequences is actively evolving within the genus. Successive amplification events occurring in different lineages over evolutionary time are typical of interspersed or transposable elements and secondary rearrangements of dispersed elements have been often documented in various plant groups (Arnason et al. 1984, Hagemann et al. 1993, Schmidt and Kudla 1996, Hanson et al. 1998, Frediani et al. 1999).

The apparent lack of a strictly sequence-dependent role of tandem repeat sequences (Charlesworth et al. 1994) may result in their rapid divergence between related species. As a consequence of the nature of evolution of repetitive sequences, acquisition and loss of restriction sites and amplification of specific repeat clusters may happen during the evolution of phyletic lineages. Thus, similar patterns are common in closely related species and may be different between lineages (Kamm et al. 1995, King et al. 1995, Cardone et al. 1997, Hall et al. 2005), suggesting potential pattern of relationships among taxa. Several species that represent closely related taxa, accordingly to available molecular and morphological phylogenetic reconstructions, effectively show similar organization and representation of dispersed repeated elements. This is the cases of the $Z$. loddigesii group, of the Caribbean species (Z. integrifolia, Z. portoricensis and Z. pumila) and of the two closely related South-American species $Z$. lecointei and $Z$. boliviana. Similarity in the hybridization pattern among closely related species may indicate the presence of phylogenetic signal in the genomic organization of the dispersed repeated elements. However attempts to fit the occurrence and organization of these repetitive elements on the molecular phylogenetic trees available for the genus (Caputo et al. 2004) do not allow the reconstruction of a unique pattern for the molecular evolution of these dispersed repeated elements in Zamia. In fact, while some species groups are characterized by similar hybridization patterns, strong variations in occurrence and genomic organization of the dispersed repeated element were also observed between closely related species as, for instance, the Panamanian Z. skinneri and Z. neurophyllidia.

The simplest model for the origin of these dispersed repeated elements involves a site-specific recombination between the AT-rich dispersed sequence and circular $\mathrm{ZpS1}$ satellite repeats occurring at a $45 \mathrm{bp}$-long common sequence (Cafasso et al. 2003). This recombination event likely took place early in the Zamia cladogenesis. In fact, the occurrence of these elements in different (all tested) Zamia lineages indicates that their evolution predates the radiation of the genus on both side of Panama isthmus. Several events of secondary amplification and losses of these dispersed repeated elements may have occurred in the long history of this ancient plant group. These secondary changes have likely hidden the evolution pattern of these dispersed repeated elements. However, a multiple and independent origin from the $\mathrm{ZpS} 1$ satellite DNA and the dispersed AT-rich element is also a possible scenario. In fact, due to the sequence homology and tandem organization of these two repetitive elements (Cafasso et al. 2003), we cannot rule out that both insertion and excision events may have occurred several times in the history of species cladogenesis. A characterization of the complete sequence of the dispersed elements will probably allow to determinate if their different genome representations in Zamia species are the consequence of several changes that occurred along a unique evolution pathway or the result of several independent events from a common genomic source. This characterization may further help to elucidate the mechanisms of genome evolution in this ancient plant group. At this regard it should be noted that in Zamia, contrarily to the other cycad genera, chromosome numbers vary greatly from species to species and, in some cases, even within species and populations (Moretti 1990b, Moretti et al. 1991). Typically, the repeat DNA organization and its chromosome distribution are related to genome evolution (Charlesworth et al. 1994, Fuchs 
et al. 1995, Lin et al. 2005) and the scattered presence in the Zamia genome of these dispersed repeated elements that contain satellite repeat arrays could be involved in the unusual karyotype variations observed in this plant group. In this regard, if centric fission is accepted as the main cause of chromosomal changes in Zamia (Moretti

\section{References}

Alix, K., Baurens, F.C., Paulet, F., Glaszmann, J.C., D'Hont, A.: Isolation and characterization of a satellite DNA family in the Saccharum complex. - Genome 41: 854-864, 1998.

Arnason, U., Höglund, M., Widegren, B.: Conservation of highly repetitive DNA in cetaceans. - Chromosoma 89: 238242, 1984.

Aron, S., De Menten, L., Van Bockstaele, D.R.: Brood sex ratio determination by flow cytometry in ants. - Mol. Ecol. Notes 3: 471-475, 2003.

Bachmann, L., Sperlich, D.: Gradual evolution of a specific satellite DNA family in Drosophila ambigua, D. tristis, and D. oscura. - Mol. Biol. Evol. 10(3): 647-659, 1993.

Bedbrook, J.R., O'Dell, M., Flavell, R.B.: Amplification of rearranged repeated DNA sequences in cereal plants. Nature 288: 133-137, 1980.

Cafasso, D., Cozzolino, S., Chinali, G., De Luca, P.: An unusual satellite DNA from Zamia paucijuga (Cycadales) characterised by two different organisations of the repetitive unit in the plant genome. - Gene 311: 69-77, 2003.

Capriglione, T., De Santo, M.G., Odierna, G., Olmo, E.: An alphoid-like satellite DNA sequence is present in the genome of a lacertid lizard. - J. mol. Evol. 46: 240-244, 1998.

Caputo, P., Cozzolino, S., De Luca, P., Moretti, A., Stevenson, D.W.: Molecular phylogeny of Zamia. - In: Walters, T., Osborne, R. (ed.): Cycad Classification, Concept and Recommendations. Pp. 149-159. Cabi Publishing, Cambrige 2004.

Cardone, D.E., Feliciello, I., Marotta, M., Rosati, C., Chinali, G.: A family of centromeric satellite DNAs from the European brown frog Rana graeca italica. - Genome 40: 774-781, 1997.

Charlesworth, B., Sniegowski, P., Wolfgang, S.: The evolutionary dynamics of repetitive DNA in eukaryotes. Nature 371: 215-220, 1994.

Dolezel, J., Bartos., J.: Plant DNA flow cytometry and estimation of nuclear genome size. - Ann. Bot. 95: 99-110, 2005.

Doyle, J.J., Doyle, J.L.: A rapid DNA isolation procedure for small quantities of fresh leaf tissue. - Phytochem. Bull. 19: 11-15, 1987.

Frediani, M., Gelati, M.T., Maggini, F., Galasso, I., Ceccarelli, M., Cionini, P.G.: A family of dispersed repeats in the genome of Vicia faba: structure, chromosomal organization, redundancy modulation, and evolution. - Chromosoma 108: 317-324, 1999.

Fuchs, J., Brandes, A., Schubert, I.: Telomere sequence localization and karyotype evolution in higher plants. Plant. Syst. Evol. 196: 227-241, 1995.

Hagemann, S., Scheer, B., Schweizer, D.: Repetitive sequences in the genome of Anemone blanda: identification of tandem arrays and of dispersed repeats. - Chromosoma 102: 312324, 1993.

Hall, S.E., Luo, S., Hall, A.E., Preuss, D.: Differential rates of and Sabato 1984), such a type of occurrence of repeated sequences scattered along the chromosomes, producing many areas of sequence homology in different chromosomes, could influence correct chromosome pairing and promote chromosome rearrangements.

local and global homogenization in centromere satellites from Arabidopsis relatives. - Genetics 170: 1913-1927, 2005.

Hanson, R., Zhao, X., Islam-Faridi, M.N., Paterson, A.H., Zwick, M.S., Crane, C.F., Mcknight, T.D., Stelly, D.M., Price, H.J.: Evolution of interspersed repetitive elements in Gossypium (Malvaceae). - Amer. J. Bot. 85: 1364-1368, 1998.

Harding, R.M., Boyce, A.J., Clegg, J.B.: The evolution of tandemly repetitive DNA: recombination rules. - Genetics 132: 847-859, 1992.

Johnson, L.: The families of cycads and the Zamiaceae of Australia. - Proc. Linn. Soc. New South Wales 84: 64-117, 1959.

Kamm, A., Galasso, I., Schmidt, T., Heslop-Harrison, J.S.: Analysis of a repetitive DNA family from Arabidopsis arenosa and relationships between Arabidopsis species. Plant mol. Biol. 27: 853-862, 1995.

King, K., Jobst, J., Hemleben, V.: Differential homogenization and amplification of two satellite DNAs in the genus Cucurbita (Cucurbitaceae). - J. mol. Evol. 41: 996-1005, 1995.

Kováŕová, P., Navrátilová, A., Macas, J., Doležel, J.: Chromosome analysis and sorting in Vicia sativa using flow cytometry. - Biol. Plant. 51: 43-48, 2007.

Kubis, S., Schmidt, T., Heslop-Harrison, J.S.: Repetitive DNA elements as a major component of plant genomes. - Ann. Bot. 82: 45-55, 1998.

Leitch, I.J., Bennett, M.D.: New insights into patterns of nuclear genome size evolution in plants. - Curr. Genom. 3: 551-562, 2002.

Lin, J.Y., Jacobus, B.H., San Miguel, P., Walling, J.G., Yuan, Y., Shoemaker, R.C., Young, N.D., Jackson, S.A.: Pericentromeric regions of soybean (Glycine max L. Merr.) chromosomes consist of retroelements and tandemly repeated DNA and are structurally and evolutionarily labile - Genetics 170: 1221-1230, 2005.

Macas, J., Navratilova, A., Koblizkova, A.: Sequence homogenization and chromosomal localization of VicTR-B satellites differ between closely related Vicia species. Chromosoma 115: 437-447, 2006.

Marchant, C.J.: Chromosome patterns and nuclear phenomena in the cycads families: Stangeriaceae and Zamiaceae. Chromosoma 24: 100-134, 1968.

Moretti, A.: Cytotaxonomy of cycads. - Mem. New York Bot. Garden 57: 114-122, 1990a.

Moretti, A.: Karyotypic data on North and Central American Zamiaceae (Cycadales) and their phylogenetic implications. - Amer. J. Bot. 77: 1016-1029, 1990b.

Moretti, A., Caputo, P., Gaudio, L., Stevenson, D.W.: Intraspecific chromosome variation in Zamia (Zamiaceae, Cycadales). - Caryologia 44: 1-10, 1991.

Moretti, A., Sabato, S.: Karyotype evolution by centromeric fission in Zamia (Cycadales). - Plant Syst. Evol. 146: 215223, 1984. 
Norstog, K.J.: Chromosome numbers in Zamia (Cycadales). Caryologia 33: 419-428, 1980.

Norstog, K.J., Nicholls, T.J. (ed.): The Biology of the Cycads. Cornell University Press, Ithaca 1997.

Ohri, D., Khoshoo, T.N.: Genome size in gymnosperms. - Plant Syst. Evol. 153: 119-132, 1986.

Pich, U., Fritsch, R., Schubert, I.: Closely related Allium species (Alliaceae) share a very similar satellite sequence. - Plant Syst. Evol. 161: 255-264, 1996.

Sambrook, J., Fritsch, E.F., Maniatis, T.: Molecular Cloning: a Laboratory Manual. - Cold Spring Harbor Laboratory Press, Cold Spring Harbor - New York 1989.

Schmidt, T., Kudla, J.: The molecular structure, chromosomal organization, and interspecies distribution of a family of tandemly repeated DNA sequences of Antirrhinum majus L. - Genome 39: 243-248, 1996.

Schutzman, B., Vovides, A.P., Dehgan, B.: Two new species of Zamia (Zamiaceae, Cycadales) from Southern Mexico. Bot. Gaz. 149: 347-360, 1988.

Sharma, S., Raina, S.N.: Organization and evolution of highly repeated satellite DNA sequences in plant chromosomes. Cytogenet. Genome Res. 109: 15-26, 2005.
Stevenson, D.W.: Morphology and systematics of the Cycadales. - Mem. New York Bot. Garden 57: 8-55, 1990.

Stevenson, D.W.: A formal classification of cycads. - Brittonia 44: 220-223, 1992.

Stevenson, D.W., Moretti, A., Gaudio, L.: A new species of Zamia (Zamiaceae) from Belize and the Yucatan Peninsula of Mexico. - Delpinoa 37-38: 3-8, 1998.

Stevenson, D.W., Osborne, R., Hill, K.: The world list of cycads. - In: Vorster, P. (ed.): Proceedings of the Third International Conference on Cycad Biology. Pp. 55-64. Cycad Society of South Africa, Stellenbosch 1995.

Uberall, I., Vrána, J., Bartoš, J., Šmerda, J., Doležel, J., Havel, L.: Isolation of chromosomes from Picea abies and their analysis by flow cytometry. - Biol. Plant. 48:199-203, 2004.

Vovides, A.P., Olivares, M.: Karyotype polymorphism in the cycad Zamia loddigesii (Zamiaceae) of the Yucatan Peninsula, Mexico. - Bot. J. Linn. Soc. 120: 77-83, 1996.

Yang, X.M., An, L.Z., Xiong, Y.C., Zhang, J.P., Li, Y., Xu, S.J.: Somatic embryogenesis from immature zygotic embryos and monitoring the genetic fidelity of regenerated plants in grapevine. - Biol. Plant. 52: 209-214, 2008. 